\title{
MPS 法を用いた雪崩 シミュレーションモデルの実用化に向けた検討 REFINEMENT OF MPS METHOD FOR PRACTICAL APPLICATION ON LARGE SCALE SNOW AVALANCHES
}

\author{
加藤宏隆 1 ・大槻政哉 2 -齋藤佳彦 2 ・清水康行 ${ }^{3} \cdot$ 木村一郎 4 \\ Hirotaka KATO,Masaya OTSUKI,Yoshiki SAITO, \\ Yasuyuki SHIMIZU and Ichiro KIMURA
}

\author{
1学生会員 北海道大学大学院 北方圈環境政策工学専攻 ( \\ 2非会員 株式会社雪研スノーイーターズ （†064-0804 札幌市中央区南4条西6丁目11-2全日ビル7F） \\ 3正会員 工博 北海道大学公共政策大学院教授 （下060-0809 札幌市北区北9条西7丁目） \\ 4正会員 工博 北海道大学大学院工学研究院准教授 （广060-8628 札幌市北区北13条西8丁目）
}

This study presents some considerations on the possibility of practical utilization of MPS method for simulating snow avalanches from engineering points of view. The MPS method is a powerful tool to reproduce flow phenomenon with large scale surface deformation. In order to apply this method to snow avalanches, we introduce a constitutive equation of Bingham and Dilatant fluid. Erosion-deposition and effects of drag force due to air are also incorporated into the model. The modified model was applied to some cases and evaluated the model performances through comparison with experimental results and observed data.

Key Words : snow avalanche, numerical simulation, MPS method, Bingham fluid, Dilatant fluid

\section{1. はじめに}

冬期災害防止の観点から，雪崩災害防止の雪崩防護施 設建設は重要な課題である. 発生した雪崩を減勢させる 減勢工に関しては，数多くの模型実験 ${ }^{1)}$ が行われている が，減勢効果の評価手法の考え方は確立されていない. このため, 減勢工の設計は経験に頼っているのが現状で あり，安全性・経済性の面から物理的根拠に基づく合理 的な減勢工の設計方法が求められている. しかし, 雪崩 は現地観測データがきわめて少なく, 現地スケールでの 検討を行うには信頼できる数值計算モデルの構築が望ま れる.

雪崩の数值計算モデルについては，これまで大きく4 つのモデルが提案されている ${ }^{2)}$ が，本研究では粉体の集 まりである雪崩を流体とみなす流体モデルを用い，連続 体の基礎式のLagrange的な離散化を可能とする粒子法 $\left(\mathrm{MPS}\right.$ 法 $\left.^{3)}\right)$ の適用について検討する．MPS法は雪崩 のような流体表面が激しく変化する現象を再現するのに 最適と言われており，減勢工周りの複雑な挙動にも適応 できると考えられる.

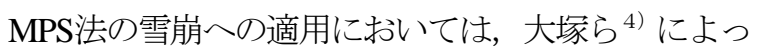
てビンガム流体を仮定した構成則および空気抵抗の導入 に対する報告があるものの，実用化に向けてはいくつか
の課題が残されている.

その一つが実地形への適用である. 流型雪崩を想定し た非ニュートン流体モデルでは，スランプ試験による再 現性の検証が行われているものの，実地形を対象とした 検討はなされていない. 実地形への適用においては, ス ランプ試験では評価出来なかった高せん断ひずみ時の挙 動を再現する為にモデルの改良を行う.

また，煙り型雪崩については，空気抵抗の導入によっ て最高速度の再現性向上が確認できているが，実用化に 向けては更なる精度向上が求められる.

以上の課題に対し, 本研究では次の 2 点について検討 を行う。

(1)煙り型雪崩の再現性向上に向けて，法線ベクトルを用 いた空気抵抗作用方向の見直し，および投影面積に関す る検討.

(2)観測データの再現性向上に向けて，雪崩をダイラタン 卜流体と仮定した場合の構成則の検討，及び侵食・堆積 モデルの導入に関する検討.

これらの計算結果の検証には，(1)ついてはピンポン 玉雪崩実験 ${ }^{5)}$ ，(2)にいては上石らによる新潟における 雪崩の実測データ 6$)$ を用いる. 


\section{2. 基礎式と数值計算モデル}

\section{（1）空気抵抗を考慮した流体の支配方程式}

流体をニュートン流体と仮定し，その連続式を式(1)に， 運動方程式を式(2)にそれぞれ示す。

$$
\begin{gathered}
\frac{D \rho}{D t}=0 \\
\rho \frac{D u_{i}}{D t}=-\frac{\partial p}{\partial x_{i}}+\rho \nu \nabla^{2} u_{i}-\rho \delta_{i 2} g-\frac{1}{V} F_{a}
\end{gathered}
$$

ここに, $\rho$ : 粒子の密度, $u$ : 速度, $p$ : 圧力, $v$ : 動 粘性係数, $g$ : 重力加速度, $V:$ MPS法の粒子一つが代表 する体積, $F_{a}$ : 空気抵抗を表している.

空気抵抗 $F_{a}$ は抗力の式より, 式(3)のように表される.

$$
F_{a}=\frac{1}{2} \rho_{a} C_{D} S u|u|
$$

ここに, $\rho_{a}$ : 空気の密度, $C_{D}$ : 抗力係数, $S$ : MPS法 の粒子一つが代表する投影面積を表している. 抗力係数 $C_{D}$ は，ピンポン玉が球体であることからレイノルズ数 Reの值により変化するSchiller and Naumanの式を用いる

$$
C_{D}= \begin{cases}\frac{24}{\operatorname{Re}}\left(1+0.15 \mathrm{Re}^{0.687}\right) & \mathrm{Re} \leq 1000 \\ 0.4 & \mathrm{Re}>1000\end{cases}
$$

（2）非ニュートン流体の構成モデル

雪崩の停止までのメカニズムを計算に取り込むために, 低せん断ひずみにおいては雪崩をビンガム流体と仮定す る. 一方，実測データを再現する大規模計算においては 高せん断ひずみ領域に達する．雪は高せん断ひずみにお いてダイラタント流体としての性質を示寸ことが知られ

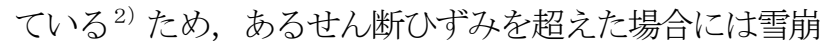
をダイラタント流体と仮定し，それぞれの流体モデルに ついて構成方程式の改良を試みる。

雪崩を非圧縮性，非ニュートン流体と仮定し，その連 続式を式(5)に，運動方程式を式(6)に示寸.

$$
\begin{gathered}
\frac{D \rho}{D t}=0 \\
\rho \frac{D u_{i}}{D t}=-\frac{\partial p}{\partial x_{i}}-\rho \delta_{i 2} g+\frac{\partial \tau_{i j}}{\partial x_{j}}
\end{gathered}
$$

ここに, $\rho$ : 粒子の密度, $u$ : 速度, $p$ : 圧力, $\tau_{i j}$ : せん断 応力, $g:$ 重力加速度を表している.

非ニュートン流体においては，式(6)中の $\tau_{i j}$ を次のよう に表すことができる.

$$
\tau_{i j}=\eta(\dot{\gamma}) \dot{\gamma}
$$

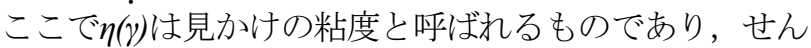
断ひずみは式(8)を使って計算される.

$$
\dot{\gamma}=\sqrt{\frac{1}{2} \dot{e}_{i j} \dot{e}_{i j}}
$$

ここに $e_{i j}$ は第二普遍量の偏差ひずみ速度テンソルである

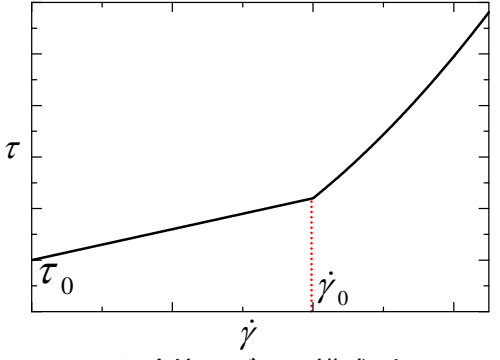

図-1 流体モデルの構成則

a) ビンガム流体の構成則

せん断応力 $\tau_{i j}$ をビンガムモデルを用いて表した場合, 次式のようになる.

$$
\begin{cases}\tau_{i j}=\eta \dot{\gamma}+\tau_{0} & \tau_{i j} \geq \tau_{0} \\ \dot{\gamma}=0 & \tau_{i j}<\tau_{0}\end{cases}
$$

ここで, $\eta$ : 塑性粘度, $\tau_{0}$ : ビンガム降伏值, $\dot{\gamma}$ : せん断 ひずみである。

ビンガム流体の構成則については大塚ら ${ }^{4)}$ と同様に, 以下の式を用いる．詳しくはそちらを参照されたい．

$$
\eta^{\prime}=\eta+\frac{c+p \tan \phi}{\dot{\gamma}}\left(1-e^{-m \dot{\gamma}}\right)
$$

\section{b) ダイラタント流体の構成則}

あるせん断ひずみを超えた場合にダイラタント流体と しての性質を示寸とき, せん断応力 $\tau_{j j}$ は次式で表される.

$$
\tau_{i j}=k \dot{\gamma}^{2} \quad \dot{\gamma}>\dot{\gamma}_{0}
$$

ここに， $k$ : 比例定数, $\gamma_{0}$ : せん断ひずみ境界值である.

すなわち, 本研究で仮定している非ニュートン流体の 構成モデルでは，せん断ひずみ境界值以下では雪崩はビ ンガム流体としての挙動を示し，せん断ひずみ境界值を 超えた際にはダイラタント流体としての挙動を示寸.

ここで，ダイラタント流体についてもビンガム流体同 様，式(11)をせん断ひずみ $\gamma$ で除すことで，ニュートン粘 性と等価な粘性を作る.

$$
\eta^{\prime}=k \dot{\gamma}
$$

また比例定数 $k \dot{\alpha}=\dot{\gamma}=\dot{\gamma}_{0}$ における式(9) と式(11)の交点か ら次式によって求める.

$$
k=\frac{\eta \dot{\gamma}_{0}+c+p \tan \phi}{\dot{\gamma}_{0}^{2}}
$$

ビンガム流体，およびダイラタント流体を組み合わせ た流体モデルの概要を図-1に示す.

\section{c) 堆積・侵食モデル}

雪崩の実測データの再現をするために，雪粒子の巻き 込み，および雪崩粒子の堆積の導入を考える. 式(9)は降 伏後のせん断応力を示しており, 降伏前のせん断応力を 算出することが出来ない，そこで本研究では，粒子に作 用寸る圧力 $p$ を各粒子に作用寸る外力とみなし，せん断 強度との大小関係によって侵食・堆積を簡易的に判定す る. 侵食・堆積の判定条件を式(14)に示寸. 


$$
\begin{cases}\tau_{0}<p & : \text { 侵食 } \\ \tau_{0} \geq p, v<0.5 m / s & : \text { 堆積 } \\ \text { other } & \text { :変化無し }\end{cases}
$$

ここで，粒子が空中に存在し圧力が作用しない場合を省 くために，堆積条件に速度の条件を加えている．侵食・ 堆積を考慮した計算では，斜面表層に侵食対象となる粒 子を配置しており，式(14)の条件を満たした粒子につい て侵食対象粒子と流体粒子を入れ替える事で，侵食・堆 積を表現している.

(3) MPS法について ${ }^{3)}$

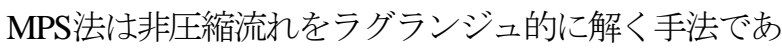
る. 数值解析手法の分類では粒子法として位置づけられ ており，微分演算子を粒子間の相互作用によって表現す ることに特徵がある.

MPS法は連続体を有限個の粒子に置き換え，式(15)で 表される重み関数 $w$ を用い，粒子間相互作用を解く.

$$
w(r)= \begin{cases}r_{e} / r-1 & r \leq r_{e} \\ 0 & r>r_{e}\end{cases}
$$

ここで, $r$ : 粒子間距離, $r_{e}$ : 粒子相互作用の及ぶ影響範 囲の半径である.

また，粒子数密度 $n$ は重み関数を用いて次式で定義す る.

$$
\langle n\rangle_{i}=\sum_{j \neq i} w\left(\left|r_{j}-r_{i}\right|\right)
$$

式(16)は粒子 $i$ において, 粒子 $i$ と各近傍粒子 $j$ との重みの 和を表している.

具体的な離散化手法，計算アルゴリズムについては越 塚 ${ }^{3)}$ と同様な手順を用いている。詳しくはそちらを参照 されたい.

\section{3. モデルの改良}

\section{（1）空気抵抗を考慮したモデル}

\section{a) モデルの改良点}

雪崩の空気抵抗のMPS法への導入を目指し, 本研究で は粒子径や密度が均一で, かつ実験結果の存在するピン ポン玉雪崩を再現できるモデルについて検討した．式(1), 式(2)を基礎式にしたモデルで，ピンポン玉の雪崩実験の 再現計算を試みる。ピンポン玉はその密度が雪崩とほぼ 同様であり，空気中への巻き上がりや空気抵抗の影響な ぞの点で雪崩と同様な挙動を示す.

空気抵抗については大塚らのモデル4）をべースに次の 2点について改良を行った.

・投影面積の与え方

計算で用いる粒子を一辺が平均粒子間隔の立方体では なく, 直径が平均粒子間隔の球体であると仮定し, 同体 積分のピンポン玉を代表しているとした.

この理由には以下の二点がある. 一点目は，MPS法の 一つの粒子の影響範囲が，平均粒子間隔を直径とする球 形を代表している点である，二点目は，球形と仮定する
ことでピンポン玉と同様の空隙率が再現でき，流体の総 重量の整合性がとれる点である.

投影面積の与え方については大塚らと同様，式(3)中の 投影面積Sには本来のピンポン玉の投影面積を与え，仮 定した球体の投影面内にあるピンポン玉数を係数として 投影面積Sに乗じている.

・空気抵抗の働く粒子の判定方法

大塚らのモデルでは，粒子数密度 $n^{*} か ゙ ， n^{*}<0.97 n^{0}$ を満 たす粒子を自由表面上に存在すると判定し，式(2)中の空 気抵抗 $F_{a}$ は自由表面上の粒子に作用するとした。

しかし実際の雪崩においては，自由表面上の粒子の中 でも雪崩前面の粒子にのみ空気抵抗は作用する，そこで 本研究では, 自由表面粒子について法線ベクトル 31 を算 出し, 雪崩の流下方向と法線ベクトルの向きから空気抵 抗の働く粒子の判定を行った. また, 式(3)を単位法線べ クトルを用いて式(17)のように書き換える.

$$
F_{a}=\frac{1}{2} \rho_{a} C_{D} S u|u| \cdot n
$$

ここに, $\rho_{a}$ : 空気の密度, $n$ : 単位法線ベクトルである 粒子一つ一つに対して抵抗を与える必要のあるMPS法 では, 自由表面粒子に式(3)に示寸単一球体の抵抗を与 えることで簡易的に空気抵抗を表現していた．しかしな がら，この従来のモデルでは一つの連続体としての挙動 を示寸雪崩全体の抵抗が再現できない，そこで，雪崩の 形状による空気抵抗の制約を取り込む事で, 連続体とし ての挙動を考慮する一つの試みとして, 法線ベクトルを 用いている.

\section{b) 計算領域}

計算に用いた札幌市宮の森スキージャンプ台の概要を 図-2に示寸．MPS法では，壁などについても粒子として 粒子数密度 $n$ を計算する必要があるため, 流体及び構造 物を粒子の配列によって表す必要がある．本計算は個別 要素法と異なり計算粒子をピンポン玉径と同じにとる必 然性は無い. 計算精度の点から計算粒子間隔は小さくと ることが望ましいが，本研究では計算負荷およびメモリ の制約上，平均粒子間隔0.2mでピンポン玉及びスロープ を表現した.

\section{c) パラメータの算定}

ピンポン玉実験の再現計算を行う上でパラメータとな る值は，粒子および壁面の粘性係数である．粘性係数に ついては以下の実験式 ${ }^{2)}$ を参考にした。

$$
\eta=1.62 \times 10^{-6} \exp \left(0.0255 \rho_{s}\right)
$$

ここに， $\rho_{s}$ : 雪の密度である，計算においては，式(18) 中の粘性係数を密度で除した動粘性係数をパラメータと して用いている. しかしながら，ピンポン玉と雪では異 なった性質を持つ. そこで, 動粘性係数の影響を検討す るために，表-1に示す4ケースについて，予備計算を 行った. すべてのケースにおいて, ピンポン玉の密度 $\rho$ は87.7kg/m光用いている. また，予備計算では，投影面 積を立方体と仮定し，法線ベクトルを用いていない条件 
で計算を行っている.

図-3は予備計算結果の流下距離と流下速度の関係を示 した図である。流下速度に関して動粘性係数の影響は見 られなかったため，モデルの検討にはRun1のパラメー タを用いることとする。

\section{d) 計算条件}

計算ケースは表-2に示す5ケースである．法線ベクトル の有無，仮定する投影面の形状の違いによる4ケースに 加え，空気抵抗の効果を考慮するために空気抵抗を考慮 しない場合についても計算を行なっている.

\section{e) 結果と考察}

流下速度の検討を行うために，雪崩先端粒子の速度と 流下距離をピンポン玉雪崩実験と比較したものを図-4に 示す．また，流下形状の比較を行うために6秒後の流下 状況を図-5に示す．図-5の計算結果においては，各粒子 の相互作用の影響を検討するため，影響範囲内に他の粒 子が存在しない粒子を赤色，粒子数密度 $n^{*}<0.97 n^{0}$ を満た す自由表面粒子を黄色，それ以外の空気抵抗を考慮しな い粒子を青色で示している.

法線ベクトルの効果は，Run5とRun7の比較から法線 ベクトルを考慮した方が流下速度が大きくなっている.

これは法線ベクトルの向きによって空気抵抗の効果が制 限されているためである。計算では図-5に黄色で示す粒 子に対して法線ベクトルの効果を与えており，大部分の 粒子が法線ベクトルによる空気抵抗の制限を受けている ことが見て取れる.

投影面積については，Run5とRun6の結果から球体と 仮定することで最高速度が抑制されている。この原因は， 式(2)の右辺第三項において，投影面の形状によって変化 する投影面積 $S$ と体積 $V$ との比 $S / V$ を平均粒子間隔 $D$ を用 いて表した場合，立方体を仮定すると $1 / D$ ，球体を仮定 すると $3 / 2 D$ となり，球体を仮定することで空気抵抗の効 果が立方体を仮定した場合の3/2倍になるためである.

最高速度の再現性の点では，法線ベクトルを考慮せず 投影面を球体と仮定したRun6が最も良い結果となって いる.しかしながら本研究では直径 $3.78 \mathrm{~cm}$ のピンポン玉 に対し，計算においては平均粒子間隔を $0.2 \mathrm{~m}$ と仮定して いるため，十分な粒子数密度を得られず，法線ベクトル の効果を正確に計算出来ていないことが考えられる.

同様に，図-5に示す流下形状が実験のようにまとまり を持った形状を示さなかった理由も粒子数密度の不足が 原因と考えられる.

そのため法線ベクトルの効果，及び本モデルの再現性 の検討については，今後，十分な粒子数密度を確保でき る手法を検討した上で評価する必要があると考える。

また，いずれのケースにおいても，最大速度が実験值 に比べて手前に出現している，これは，実験と計算の初 期条件の違いによるものであると考えられる．実験では， 下端固定の扉を開けることでピンポン玉が流下を開始す る.この時，ピンポン玉は扉の動きに合わせて上端から
表-1 予備計算ケース

\begin{tabular}{|c|c|c|}
\hline & $\begin{array}{c}\text { 粘性項の } \\
\left(\mathrm{m}^{2} / \mathrm{s}\right)\end{array}$ & $\begin{array}{c}\text { 底面摩擦力項 } \\
\text { の } v\left(\mathrm{~m}^{2} / \mathrm{s}\right)\end{array}$ \\
\hline Run1 & $2.3 \times 10^{-6}$ & $1.15 \times 10^{-5}$ \\
\hline Run2 & $2.3 \times 10^{-6}$ & $2.3 \times 10^{-6}$ \\
\hline Run3 & $1.15 \times 10^{-5}$ & $2.3 \times 10^{-6}$ \\
\hline Run4 & $1.15 \times 10^{-5}$ & $1.15 \times 10^{-5}$ \\
\hline
\end{tabular}

表-2 計算ケース

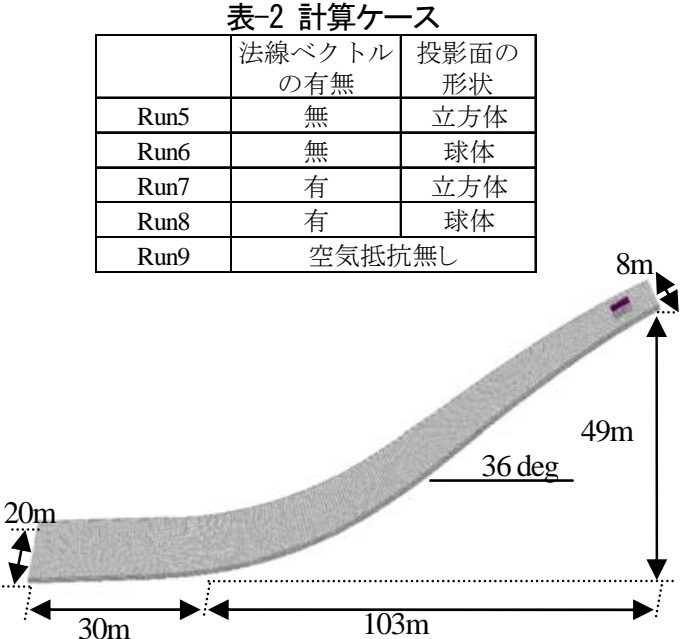

図-2 スキージャンプ台の概要

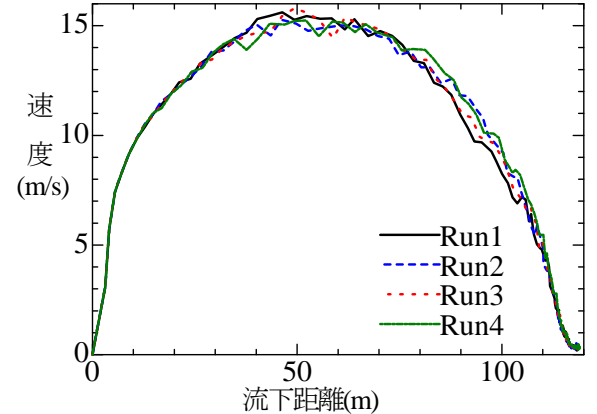

図-3 予備計算結果

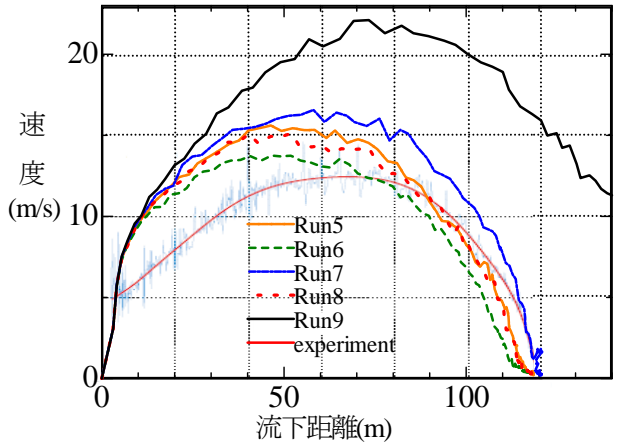

図-4 計算結果

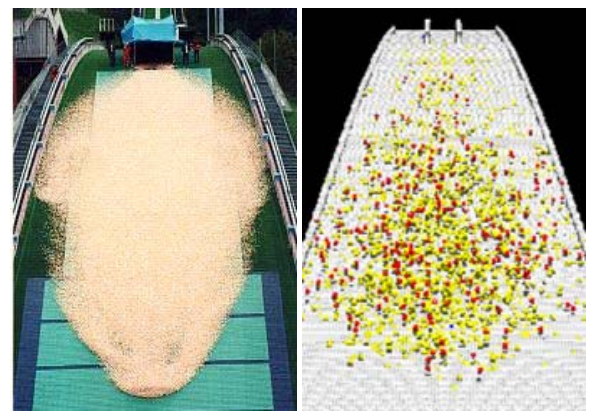

図-5 形状の比較 (6秒後)

（左：観測データ，右：計算結果） 
滑り落ちるように流下を開始する。一方計算においては 扉を考えていないため，流下開始時の挙動が扉に制限さ れる事なく, 静水圧の大きい下端から流下を開始寸る. 計算においては，これらの違いが原因で初期流下速度が 実験に比べ大きくなっていると考えられる．最高速度の 再現性の最も高いRun6は，90m-120mの区間で他のケー スに比べ再現性が低下しているが，これについても初期 流速の不適合が原因と考えられる.

\section{（2）MPS法への非ニュートン流体モデルの導入}

\section{a) 改良方法}

せん断ひずみが小さい場合の挙動については大塚らに よってビンガム流体の適用が試みられているが，あるせ 儿断ひずみ以上になった場合には，せん断応力がせん断 ひずみの2乗に比例して急激に増加するダイラタント流 体の性質を示すことが実験的に確認されている ${ }^{2)}$. 本研 究ではビンガム流体とダイラタント流体の境界となるせ ん断ひずみの境界值を, 実験值を元に $\gamma_{0}=5.0$ としている. b) 計算条件

モデルの検証については，新潟県で発生した雪崩の実

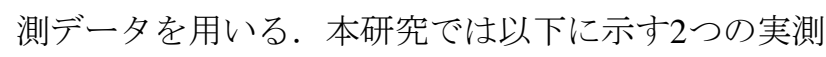
データ ${ }^{6)}$ につい再現計算を試みる.

・case1 : 新潟県長岡市で発生した雪崩であり，その斜 面の概要を図-6に示す。case1は雪崩流下範囲，およ び堆積状況について検証を行う.

・case2 : 新潟県山古志トンネル付近で発生した雪崩で あり, 斜面の概要を図-7に示す. 発生区から対象領域 内の最も低い地点までの高低差はおよそ90mである.

Case2では主に流下速度と流下経路について検証する. パラメータは，上石ら同様の実測データについて再現 計算を行った際に用いたパラメータと同様に, 粘着力 $c: 100(\mathrm{~Pa})$, 内部摩擦角 $\phi: 24\left(^{\circ}\right)$, 塑性粘度 $\eta: 0.01$ : $(\mathrm{Pa} \cdot \mathrm{s})$ とした。 また, 底面粒子と流体粒子との境界は ニュートン流体とし, 動粘性係数 $6.25 \times 10^{-2}\left(\mathrm{~m}^{2} / \mathrm{s}\right)$ を与え ている. 平均粒子間隔は計算負荷を考慮し $0.5 \mathrm{~m}$ と，侵 食の対象となる粒子は底面の表層 $25 \mathrm{~cm}$ 仮定した.

\section{c)計算結果と考察}

\section{• case1について}

観測結果を図-8に，30秒後の計算結果を図-9に示寸.

図-9中(左)が大塚らによるビンガム流体を仮定したモデ ル，(右)が大塚らのモデルにダイラタント流体，侵食・ 堆積モデルを導入した計算結果である. ビンガム流体を 仮定したモデルでは流下粒子を青で表現しているが，侵 食堆積を考慮したモデルでは粒子の入れ替えを行なって いるため, 侵食された領域では灰色の壁粒子が露出し, 堆積粒子・侵食対象粒子は白色で示している.

流下範囲について, ビンガム流体のみの計算では流下 範囲が広範囲に及んでいるのに対し, ダイラタント流体 を仮定した本モデルでは水平方向の拡がりが制約され， 実測データを良好に再現出来ていることが見て取れる.
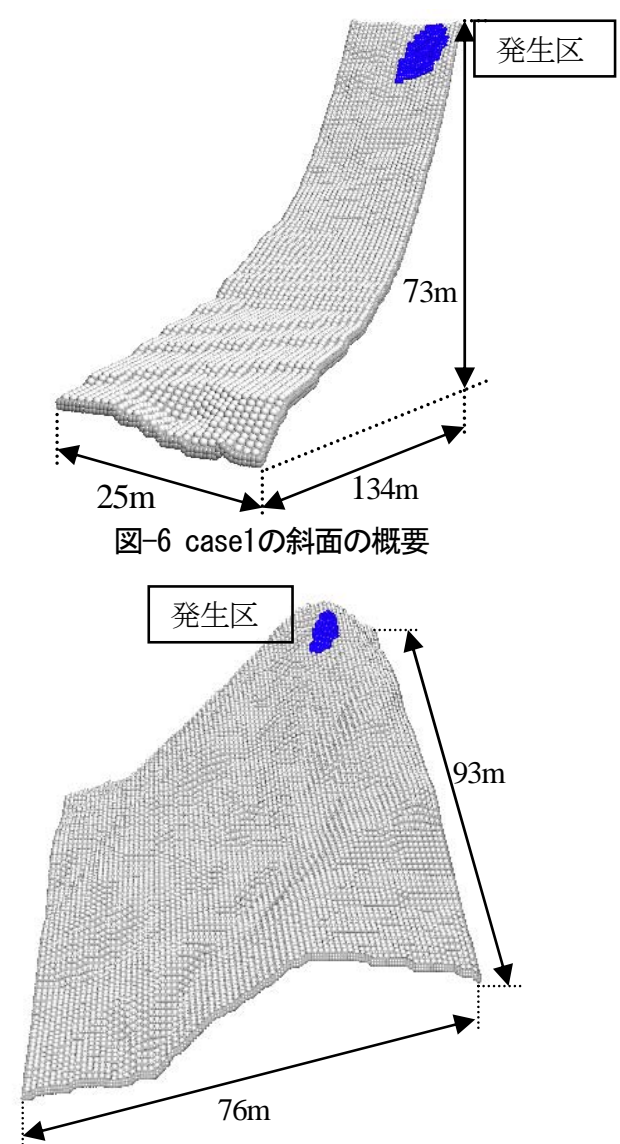

図-7 case2の斜面の概要

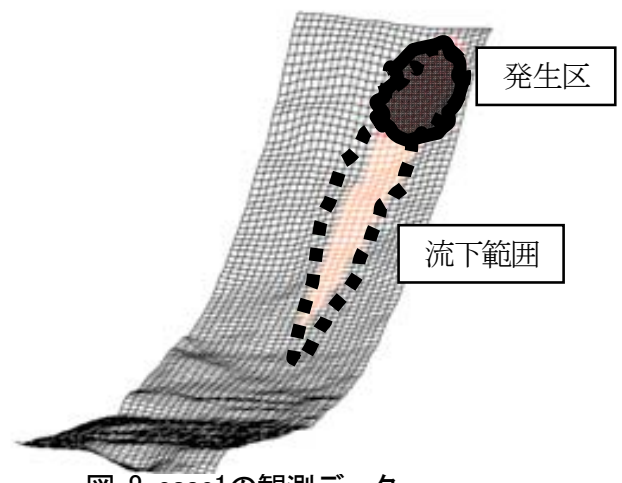

図-8 case1の観測データ
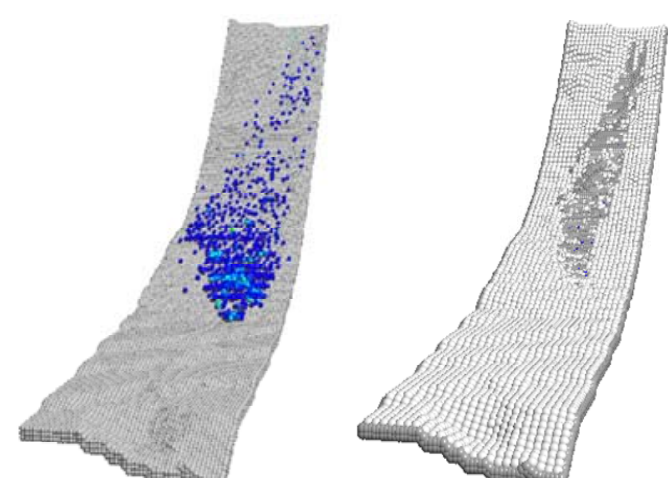

図-9 case1流下範囲 (30秒後)

（左 : ビンガム流体モデル）（右 : ダイラタント流体モデル 十侵食・堆積を考慮) 
流下距離については, 計算結果の経過時間と流下距離 の関係を図-10に示す．ビンガム流体のみのモデルでは 雪崩の停止を再現出来なかったが，堆積モデルを導入す ることで雪崩の発生から停止までを再現することができ ている.

観測データ不足のため，定量的な評価を行う事はでき ないが，目視による流下範囲，及び雪崩の停止を再現で きた点から，実用化に向けての大規模な斜面に対寸るダ イラタント流体モデルの適用可能性を示寸結果となった。 • case2について

観測データ，および計算結果を図-11に示寸．図中の (左)が観測データ，(右)が計算結果で，5秒毎の流下状況 を示している．図中では観測データの雪崩流下状況が判 断しにくいため，各時間における雪崩の先端を目視に基 づく矢印によって示している.

計算結果について定量的な評価はできないが，計算結 果は観測データの流下速度，及び流下経路を良好に再現 出来ていることが定性的に確認できる．また，侵食モデ ルを導入したことで，雪崩が壁面の雪を巻き込んで流下 していく様子が再現出来ている.

\section{4. まとめ}

本研究では, 煙り型雪崩と流れ型雪崩を仮定し，それ ぞれに対し空気抵抗項の見直し，ダイラタント流体，侵 食・堆積モデルの導入について検討を行った．その結果， 以下の結果が得られた。

1)煙り型雪崩を想定したモデルでは投影面積の見直しに よって流下速度の再現性が向上したが，法線ベクトル 導入の有効性を示すことは出来なかった。煙り型雪崩 への適用性の評価については，今後大規模計算によっ て十分な粒子数密度を確保した条件で行う必要がある。 2)流れ型雪崩を想定したモデルでは，ダイラタント流体， 侵食・堆積モデルを導入したことで発生から停止まで が表現可能になった。 また，実際に発生した雪崩の流 下範囲・流下速度について，定性的ではあるが良好な 再現性が確認できた.

今後はこの修正MPS法を用いて，雪崩減勢工周りの挙 動について定量的な評価を行っていきたい.

\section{参考文献}

1) 例えば 石田孝司，加藤信夫，上石勲：雪崩減勢工の速度 低減効果に関する模型実験, 砂防学会研究発表会概要集, Vol.1998, pp.346-347, 1998.

2) 前野紀一, 福田正己 : 基礎雪水学講座III, 古今書院, 2000.

3) 越塚誠一 : 計算レクチャーシリーズ5 粒子法, 日本計算学 会編，丸善株式会社，2005.

4) 大塚達也, 清水康行, 木村一郎, 大梘政哉, 齋藤佳彦 : MPS法の雪崩への適用に向けての二，三の検討，水工学論文 集，第53巻，pp.1063-1068， 2009.

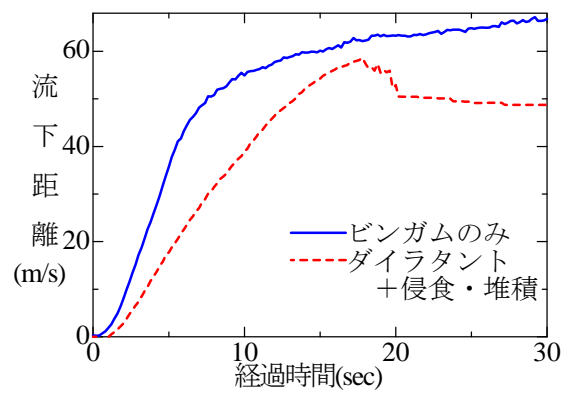

図-10 流下距離の時間変化
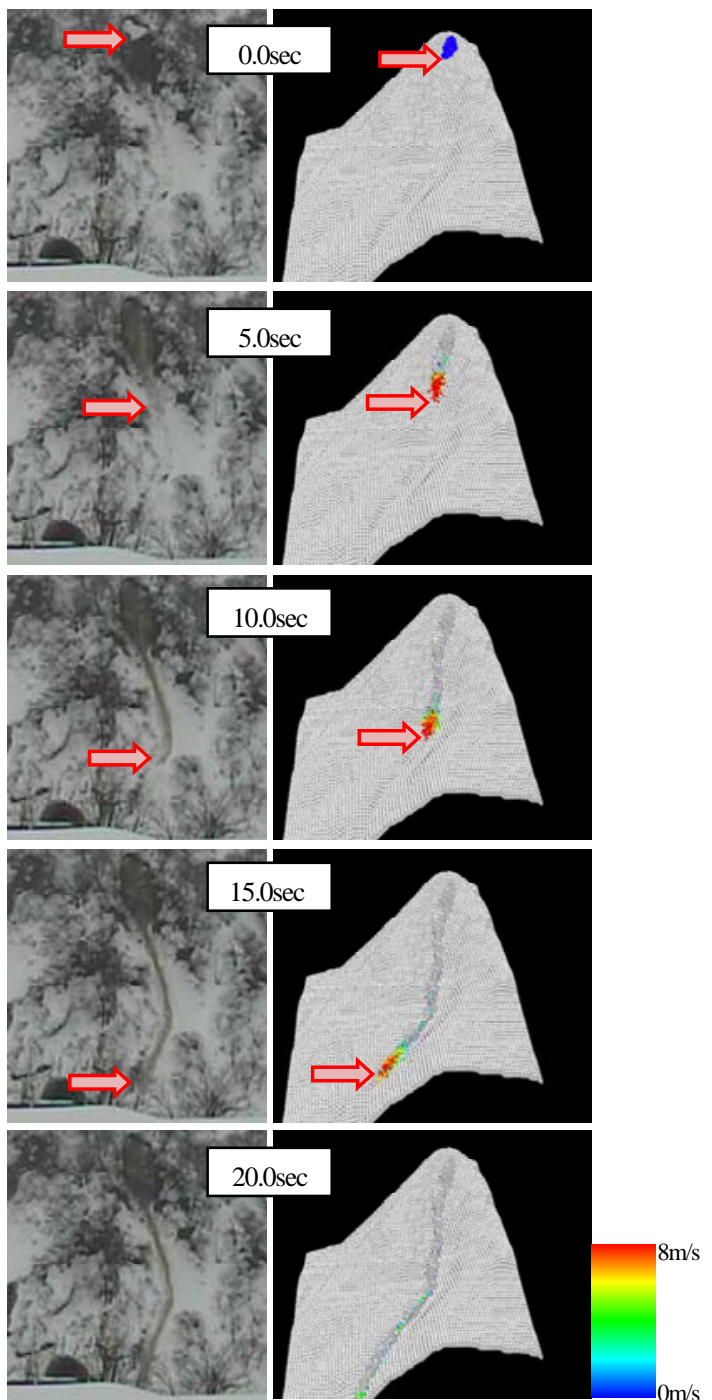

図-11 case2計算結果

（左：観測データ，右 : 計算結果）

5) 小椋崇広，MCELWAINE J，西村浩一 : 質量中心モデルを用 いたピンポン球雪崩の運動解析，雪水，Vol.65 No.2, pp.117125, 2003

6) 上石勲，小田憲一，森口周二，沢田和秀，八嶋厚,町田敬, 新潟県中越地域における雪崩の動態観測と雪崩流体運動解析 モデルの検証,雪水研究大会講演要旨集, p.105, 2010 .

(2010.9. 30受付) 